\title{
PERDAGANGAN DAN PENYELUNDUPAN PEKERJA MIGRAN INDONESIA DI MALAYSIA
}

\author{
Miswanto ${ }^{1}$, Desmayeti Arfa ${ }^{2}$ \\ Received Article: 27 Juni 2016 \\ Accepted Article: 01 November 2016
}

\begin{abstract}
Migration of workers contributes significantly to economic development both to the country of origin and to the country of received. However, there are various problems that arise from migration of workers. Trafficking and smuggling of illegal workers more recognizable as trafficking in humanity. The purpose of this study is to explore what factors influence migrant workers to come and work in Malaysia, both internal and external factors. This study use qualitative approach by describing about trafficking and smuggling of Indonesian migrant workers and quantitative approach by analyzing data from questionaires. In 2008, it was found that 35,353 Indonesian migrant workers that consist of male and female workers are returned from Malaysia. Average migrant workers who returned to Indonesia every month are 2,946 peoples. Because of limitation of time, there are only 100 respondents that distributed questionaires. This study found that there are two factors caused respondent come and work in Malaysia namely push and pull factors. Push factors consist of economic factors, environment, family, education, population crowding, high competition for jobs, safety, and exposure to natural disasters. Pull factors consist of job opportunities in Malaysia and higher income, the similarity of culture between Indonesia and Malaysia and nearess geographical position.
\end{abstract}

Keywords: Migration, Workers, Trafficking, Smuggling

\begin{abstract}
Abstrak
Pekerja migran berkontribusi secara siginifikan terhadap pembangunan ekonomi kepada negara asal migran dan negara yang dituju. Namun demikian, ada beberapa berbagai permasalahan yang muncul dari pekerja migran. Perdagangan dan penyelundupan pekerja ilegal yang lebih dikenal sebagai penyelundupan manusia. Tujuan dari kajian ini adalah mengeksplorai apakah faktor-faktor yang mempengaruhi pekerja migran yang datang dan bekerja di Malaysia, baik secara faktor internal maupun eksternal. Kajian ini menggunakan pendekatan kualitatif dengan menggambarkan tentang perdagangan dan penyelundupan pekerja migran dari Indonesia dan juga menggunakan pendekatan kuantitatif dengan menganalisis data quesioner. Pada tahun 2008, telah ditemukan sebanyak 35.353 pekerja migran Indonesia termasuk laki-laki dan perempuan yang kembali dari Malaysia. Rata-rata pekerja migran yang kembali ke Indonesia setiap bulannya sekitar 2,946 orang. Dikarenakan keterbatasan waktu penelitian, hanya 100 responden yang mengisi quesioner. Kajian ini menunjukkan bahwa terdapat 2 faktor yang menyebabkan responden datang dan bekerja di Malaysia, yaitu faktor pendorong dan faktor penarik. Faktor pendorong yaitu faktor ekonomi, lingkungan keluarga, pendidikan, kepadatan penduduk, persaingan kerja, keamana dan tekanan bencana alam. Untuk faktor penarik yaitu kesempatan bekerja lebih luas di Malaysia dan pendapatan tinggi disana, kesamaan budaya antara Indonesia dan Malaysia dan posisi geografi yang dekat antara kedua negara tersebut.
\end{abstract}

Kata Kunci: Migrasi, Pekerja, Perdagangan Manusia, Penyelundupan

\footnotetext{
${ }^{1}$ Penulis adalah Dosen Sosiologi Prodi Sosiologi STISIPOL Raja Haji Tanjungpinang

${ }^{2}$ Penulis adalah Dosen Sosiologi Prodi Sosiologi STISIPOL Raja Haji Tanjungpinang
} 


\section{A. Pendahuluan}

1. Latar Belakang

$\mathrm{M}$ igrasi pekerja yang terjadi di seluruh dunia, memberi sumbangan yang cukup besar bagi pembangunan ekonomi baik kepada negara asal pekerja yang bermigrasi atau negara yang menerima pekerja. Namun begitu, terdapat juga pelbagai masalah yang timbul dari migrasi pekerja ini, seperti perdagangan atau penyelundupan manusia secara tidak sah (ilegal) yang lebih dikenali sebagai perdagangan manusia (trafficking in humanity). Perdagangan (trafficking) meru pakan migrasi antarbangsa yang tidak sah (ilegal) dan tidak melalui proses doku mentasi yang sah dan dapat dikategorikan sebagai penyelundupan manusia dengan cara penipuan, pemaksaan dan kekerasan. Pakar memberikan definisi perdagangan (trafficking) sebagai keseluruhan tindakan yang terlibat dalam proses pengambilan dan atau apabila seorang wanita keluar dari wilayah asalnya ke daerah lain dalam negari atau luar negari untuk mencari pekerjaan atau melayani lelaki. Proses ini melibatkan kekerasan dan menggunakan kuasa serta kedudukan oleh pihak-pihak tertentu yang mempunyai kepentingan. Yang banyak menjadi korban dalam kasus ini terdiri dari wanita dan anak-anak.

Pada tahun 2000 (Natalis Pigay 2004), diseluruh dunia kira-kira 700 ribu hingga 2 juta wanita dan anak-anak yang mengalami penyelundupan. Jumlah ini meningkat pada tahun 2003. Dari jumlah tersebut 200 ribu hingga 250 ribu kasus tarjadi di Asia Tenggara. Jumlah tersebut merupakan kasus yang dilaporkan secara resmi dan masih banyak kasus yang tidak tercatat karena banyak kasus terjadi secara sembunyi dan tidak diketahui oleh pihak berwenang.

Laporan dari Bureau of Public Affairs, US Departemen of State pada bulan Juni 2003 menjelaskan bahwa setiap tahun antara 800 ribu hingga 900 ribu manusia telah diselundupkan dan menerobos sem padan antarabangsa. Penyelundupan ini terjadi untuk memenuhi pasaran pekerja seks dan pekerja buruh. Penyelundupan ini dilakukan oleh pelaku kejahatan yang mempunyai rangkaian hubungan antara bangsa (transnational criminaliti) di mana mempunyai satu organisasi yang terancang serta mempunyai hubungan dengan negara lain.

Setiap tahun, jumlah orang dewasa dan anak-anak yang menjadi korban perdagangan terus bertambah. Kira-kira 50 ribu orang telah menjadi korban perdagangan orang setiap tahun di Afrika, 75 ribu di Eropa Timur, 100 ribu di Amerika Latin dan Carribien serta 375 ribu di Asia (Ratnawati. Harga sebuah kebebasan: Isu perdagangan perempuan. 2004)

Wanita dan anak-anak dipujuk, dipaksa, dan dijual sebagai pekerja seks, buruh murah serta dipergunakan sepe nuhnya dalam pelbagai bidang lain seperti pembantu rumah tangga dan isteri kontrak (Natalis Pigay, Migrasi dan Penyelundupan Manusia, 2004).

Paksaan dan kekerasan dalam perdagangan ini menyebabkan kaum wanita dan anak terlibat sebagai pekerja seks komersil. Ini memaksa pemerintah untuk memberantas tindakan penyelundupan manusia tersebut. Kerjasama negara-negara di Asia Selatan sejak tahun 2002 telah membawa pada satu perjanjian, mence gahan dan memberantas penyelundupan manusia khususnya kaum wanita dan anakanak yang terlibat dalam pelacuran. Selain itu, Kanada, USA, Rusia serta sebahagian besar negara-negara yang ada di Asia Pasifik telah mengambil langkah untuk melakukan perbaikan tentang hak kaum wanita, anak-anak dan para migran untuk menentang tindakan penyelundupan manu sia.

Salah satu negara yang menjadi tujuan utama bagi para pekerja migran ialah Malaysia. Dengan alasan karena kedudukan Malaysia yang berdekatan dengan Indo nesia. Persamaan bahasa dan budaya serta upah yang tinggi turut mempengaruhi mereka. Jumlah pekerja wanita dari Indonesia di Malaysia pada tahun 2002 adalah sebanyak 65,114 orang. Sebahagian besar pekerja wanita bekerja di sektor industri dan swasta iaitu sebanyak 43,925 orang, sedangkan pekerja laki-laki yang bekerja di sektor industri dan swasta hanya 633 orang. Manakala pekerja yang bekerja di sektor resmi sebanyak 86,933 orang pekerja lelaki dan 21,189 pekerja wanita. 
(Korono Nicholasch. Perdagangan perem puan ke Malaysia tetap marak. 2004).

Akhir-akhir ini terjadi peningkatan penyelundupan tenaga kerja dari Indonesia ke Malaysia. Hal ini disebabkan karena kemerosotan ekonomi yang terjadi di Indonesia hingga mengakibatkan kemis kinan dan pengangguran. Penyelundupan tenaga kerja menyebabkan semakin banyak tenaga kerja Indonesia (TKI) yang kebanyakannya terdiri dari wanita beresiko tinggi terhadap ancaman kekerasan baik secara fisik, psikologi, seksual dan ekonomi karena tidak ada perlindungan. Ini juga termasuk dengan sindiket perdagangan manusia (trafficking in persons).

Pelbagai krisis yang dialami Indonesia sejak pertengahan tahun 1997 mempengaruhi peningkatan kasus perdaga ngan manusia di Indonesia. Meningkatnya jumlah keluarga miskin dan angka putus sekolah dari sekolah di pelbagai tingkat pendidikan, angka pengangguran yang meningkat dan bertambahnya konflik sosial di pelbagai daerah mendorong terjadinya perdagangan manusia.

Pekerja migran merupakan salah satu saluran yang disalahgunakan oleh sindiket perdagangan manusia di kancah internasional. Hal ini disebabkan karena lemahnya pengawasan pihak terkait ter hadap sistem dan proses pendaftaran pekerja migran. Perdagangan manusia adalah fenomena yang sangat kompleks di mana ia rentan terhadap masalah pele cehan seksual, uang, penggunaan obat terlarang atau narkoba dan perlengkapan surat-menyurat atau migrasi.

Pada masa ini, diperkirakan terdapat 2 juta manusia khususnya wanita yang diperdagangkan setiap tahun sebagai pekerja seks komersil. Perdagangan manusia menjadi sumber pendapatan yang ke-3 terbesar dalam organisasi kejahatan di dunia setelah narkoba, dan senjata. (Nursyahbani Katjasungkana. 1997).

Hal ini mendapat perhatian berbagai pihak di seluruh dunia termasuk negaranegara di Asia Tenggara. Konsep perda gangan manusia ialah perpindahan manusia (pekerja migran) dari seseorang kepada orang lain untuk tujuan memperolehi keuntungan uang atau keuntungan lain. Perdagangan pekerja migran adalah sebuah proses penjualan di antara penjual dan pembeli dengan harga yang disetujui. (Philips Jusario Vermonte. 1999).

Umumnya korban perdagangan ini terdiri dari wanita kampung yang miskin dan memiliki taraf pendidikan dan keahlian yang sangat rendah sehingga dengan mudah ditipu dan dijadikan sasaran utama bagi kejahatan perdagangan manusia. Wanitawanita tersebut dijebak oleh sindiket perdagangan melalui pelbagai cara. Keba nyakannya memberi janji kepada para pekerja di mana mereka diberikan pekerjaan yang baik dengan gaji yang tinggi atau dijanjikan bekerja dalam pelbagai bidang.

Alan Boulton, Direktur International Labour Organization (ILO) Indonesia, saat memperingati World Day Against Child Labor (ILO 2003), mengingatkan bahwa perdagangan anak dan pekerja buruh untuk tujuan eksploitasi seksual telah mencapai pada tahap yang menyedihkan. Sebahagian dari mereka diselundup ke negara-negara tetangga seperti Singapura, Malaysia, Taiwan dan Jepang. Yang lebih menyedihkan lagi, laporan ILO mendapati bahawa lebih dari 10.000 anak-anak di Indonesia di bawah umur 18 tahun diperdagangkan sebagai pekerja seksual di lima pusat kota di Indonesia. Masalah perdagangan dan penyelundupan manusia telah menempatkan Indonesia pada peringkat ketiga dalam kasus Trafficking in Persons Report (TIP) yang dikeluarkan oleh Bureau of Public Affairs, US Departement of State tahun 2003.

Beberapa usaha untuk mening katkan kebijakan berhubung hal ini seperti inisiatif Indonesia membuka kerjasama dengan negara-negara luar Bali Regional Ministerial Conference on People Smug gling, Trafficking in Persons and related Transnational Crime (Proses Bali) untuk kali kedua sebagai dasar usaha yang sungguhsungguh dalam memerangi kejahatan perdagangan dan penyelundupan manusia sebagai faktor penting dalam menaikkan posisi (kedudukan) Indonesia.

\section{Tujuan Penelitian}

$\mathrm{T}$ ujuan penulisan ini adalah untuk menganalisis faktor-faktor yang me nyebabkan terjadinya perdagangan dan penyelundupan pekerja migran Indo nesia di Malaysia yaitu: Untuk mengetahui 
faktor yang mempengaruhi pekerja migran Indonesia datang bekerja di Malaysia, fak tor yang mendorong pekerja migrant meninggalkan daerah asalnya.

\section{Metodologi}

$\mathrm{K}$ ajian ini merupakan satu kajian deskriftif kualitatif, dimana pengkaji memberikan ulasan-ulasan mengenai penelitian dengan memberikan gambarangambaran bagaimana perdagangan dan penyelundupan pekerja migran Indonesia terjadi dengan pelbagai solusi yang ditemui dalam kajian ini.

Terdapat beberapa kaedah pene litian yang digunakan untuk mendapatkan hasil kajian ini yaitu melalui pengumpulan data sekunder dan data primer berdasarkan kepada wilayah kajian; menganalisis data dan tinjauan keadaan di kawasan kajian .

\section{Populasi dan Sampel}

$\mathrm{P}$ opulasi dalam penelitian ini ialah semua pekerja migran Indonesia yang dideportasi dari Malaysia ke Tanjungpinang dan berada di tempat perlin dungan Dinas Tenaga Kerja dan Trans migrasi Kota Tanjungpinang yang menga lami kasus perdagangan dan penye lundupan. Pada tahun 2008 didapati sebanyak 35,353 orang pekerja migran Indonesia yang dideportasi dari Malaysia baik lelaki mahupun wanita.

\section{B. PEMBAHASAN}

\section{Perdagangan dan Penyelundu pan Pekerja Migran Indonesia}

lis. su perdagangan wanita di Indonesia mulai diketahui umum secara meluas dalam kongres ke-2 Persatuan Perkumpulan Isteri Indonesia (PPII) di Surabaya tahun 1930. Untuk memper kuatkan perjuangan menentang perda gangan wanita, kongres kedua PPII menubuhkan Perkumpulan Pemberantasan Perdagangan Wanita dan anak-anak (P-4A). PPII menyadari bahwa terdapat hubungan antara perdagangan wanita dan pelacuran dengan kemiskinan.
Perdagangan dan penyeludupan manusia di Indonesia bukanlah hal yang baru tetapi isu ini menjadi tumpuan utama pada tahun 2008. Perdagangan manusia melanggar hak asasi manusia. Wanita dan anak-anak adalah golongan yang rentan mengalami perdagangan. Kemajuan tekno logi juga turut dalam hal ini, di mana dengan bantuan teknologi yang canggih modus operasi penyelundupan manusia lebih mudah dijalankan. Terdapat lima faktor utama terjadinya perdagangan manusia yaitu kejahatan ini terjadi karena meng hasilkan keuntungan yang besar; korbannya wanita dan anak-anak adalah golongan yang mudah dipujuk; struktur masyarakat yang umumnya patriarkhal dan masih menempatkan wanita sebagai warga negara kelas kedua (subordinasi); peluang pekerjaan terbatas, dan kedudukan geografi Indonesia yang luas mempersulit untuk memberantas kejahatan ini.

Perdagangan wanita banyak terjadi bersamaan dengan penghantaran pekerja ke luar negari, khususnya pekerja wanita. Banyak wanita dan anak-anak yang dipindahkan dari satu tempat ke tempat yang lain, dari kampung ke kota dan ke negara lain dengan pelbagai cara yang tidak sah, tanpa persetujuan dan pemahaman atau kesadaran korban. Mereka ditipu dengan janji akan mendapat kerja yang baik dengan gaji yang tinggi. Hal itu juga dilakukan untuk kepentingan jual beli obat terlarang, peminta sedekah, pekerja seks, pekerja pabrik dan pelbagai pekerjaan lain yang mengeksploitasi mereka.

\section{Isu Perdagangan dan Penyelun dupan Pekerja Migran Indonesia di Malaysia}

ika dikaji, perdagangan dan penye ludupan manusia makin meningkat sebagai dampak krisis ekonomi. Jumlah penduduk yang tidak dan belum bekerja terutama di kampung-kampung semakin meningkat dan keperluan kehidupan semakin kompleks untuk dipe nuhi. karena segala biaya yang perlu ditanggung semakin bertambah. Sejak krisis moneter pada tahun 1998, banyak pabrik (yang sebelumnya menjadi tempat bekerja) ditutup. Keadaan ekonomi dan politik yang tidak stabil dan berkurangnya lapangan 
pekerjaan. Keadaan ini menyebabkan ba nyak orang berniat bekerja keluar negari khususnya ke Malaysia yang merupakan negara terdekat. Penceraian dan poligami yang juga mendorong wanita untuk keluar mencari kerja. Akan tetapi mereka terperangkap dengan pihak-pihak yang tidak bertanggungjawab dan menipu sehingga mereka menjadi korban perdagangan manusia.

\section{Faktor Penyebab Terjadinya Perdagangan dan Penyelundupan}

$\mathrm{P}$ erdagangan merupakan sebahagian dari dinamika penduduk. Dalam hal ini terdapat penduduk yang berpindah secara sukarela dan kadang-kala perpin dahan secara paksa untuk mengatasi masalah penduduk. Perpindahan pekerja baik secara suka rela mahupun secara paksa bukanlah fenomena baru.

Namun terdapat perbedaan dengan perdagangan dan penyelundupan yang berlaku pada masa kini yaitu migrasi antara negara. Dalam arus migrasi ini, terdapat fenomena lain yang muncul yaitu feminisasi (program migrasi yang mayoritas terjadi pada wanita dan anak-anak). Pekerjaan yang dijalankan wanita korban penye lundupan manusia bercirikan 3D iaitu Dirty, No Dignity, dan Dangerous atau kotor, tidak bermartabat dan berbahaya.

Keadaan ini semakin berterusan di negara-negara yang mengalami krisis ekonomi. Di samping itu, pekerjaan yang tersedia dalam negeri tidak sesuai dengan pekerjaan yang diinginkan. Dengan kata lain, pekerjaan yang ada tidak memberi harapan dan kehidupan yang lebih baik kepada golongan tersebut. Bagi pekerja migran, mereka tidak menyadari jika mereka tidak melalui prosedur yang ditentukan atau tidak. Apa yang mereka tahu hanyalah mereka mendapat tawaran suatu pekerjaan di suatu negara dengan jumlah tertentu atau dengan perjanjian tertentu, mereka diterima untuk bekerja. Pada akhirnya mereka menyadari bahwa mereka ditipu dan memasuki negara lain tanpa proses yang sah pada saat mereka telah berada di Malaysia.

Faktor pendorong diatas juga berkaitan dengan diskriminasi gender dalam keluarga dan masyarakat. Banyak wanita dan yang melarikan diri dari ketidakadilan gender, beban kerja yang terlalu berat dirumah atau mereka dipaksa menikah oleh orang tuanya. Dalam sebagian budaya di Indonesia, wanita tidak mendapat tempat (marginalisasi). a.

Di Malaysia terdapat 2.4 juta pekerja asing (Sujata \& Zolkepli, 2007) yang bekerja di pelbagai sektor. Pekerja yang memiliki permit menetap dan bekerja secara sah ialah 1.2 juta orang, manakala selebihnya masuk secara tidak sah atau ilegal (Berita Harian, 22 Jun 2004). Berdasarkan kepada Menteri Hal Ehwal Dalam Negeri (Malay sia), Datuk Seri Radzi Sheikh Ahmad, jumlah pekerja asing Maret 2006 ialah $1,850,063$ di mana pekerja Indonesia mencatat jumlah paling banyak (Ruhaidini 2006). Tabel 1.1 menunjukkan statistik pekerja asing di Malaysia yang mempunyai pas lawatan (permit kerja sementara) tiga bulan pertama tahun 2001 (selama tiga bulan di awal-awal tahun 2001 (jan,feb,mar)).

Tabel 1.1 Statistik Pekerja Migran yang bekerja ke Malaysia tahun 2001

\begin{tabular}{lr} 
Negara Asal & Jumlah yang beker \\
\hline 1. Indonesia & 888,000 \\
2. Bangladesh & 216,000 \\
3. Filipina & 24,000 \\
4. Iain-lain & 72,000
\end{tabular}

Sumber: Migration News, Ed. 9, no. 3, Mac 2002

Berdasarkan tabel di atas, dapat dilihat bahwa pekerja migran Indonesia berada pada tingkat pertama yaitu 888,000 orang yang bekerja di Malaysia pada tahun 2001. Tempat kedua diikuti oleh Bangladesh sebanyak 216,000 orang dan diikuti oleh Filipina yang menduduki tempat ketiga kemudian di susul oleh negara-negara lain. Pada tahun 2006, jumlah pekerja migran Indonesia yang memiliki pas lawatan (kerja sementara) dalam tempoh tiga bulan pertama yang bekerja di Malaysia mengalami peningkatan (Tabel 1.2). 
Tabel 1.2 Statistik Pekerja Migran di Malaysia yang Mempunyai Pas Lawatan (Kerja Sementara) selama Tiga Bulan Pertama tahun 2006

\begin{tabular}{|c|l|c|}
\hline Bil. & \multicolumn{1}{|c|}{ Pekerja migran mengikut Negara } & Jumlah \\
\hline 1 & Indonesia & $1,215.036$ \\
\hline 2 & Nepal & 200,220 \\
\hline 3 & India & 139,716 \\
\hline 4 & Myanmar & 92,020 \\
\hline 5 & Vietnam & 85,835 \\
\hline 6 & Bangladesh & 58,878 \\
\hline 7 & Filipina & 22,080 \\
\hline 8 & Pakistan & 15,021 \\
\hline 9 & Thailand & 7,282 \\
\hline 10 & Sri Lanka & 5,076 \\
\hline 11 & Kemboja & 6,637 \\
\hline 12 & Lain-lain & 2,262 \\
\hline
\end{tabular}

Sumber: Ruhaini Abd. Kadir (2006) dalam Chin Pek Lian (2007).

Selain kemiskinan, faktor yang menyebabkan peningkatan perdagangan dan penyelundupan pekerja migran ialah faktor pendidikan. Tingkat pendidikan yang rendah menyebabkan mereka mudah percaya kepada orang lain. Faktor-faktor lain adalah seperti perkawinan diusia muda, mudah diperdaya dengan janji-janji dan upah tinggi. Kadangkala orang tua beranggapan bahwa anak adalah sumber pendapatan dan mengizinkan anak mereka untuk bekerja ke Malaysia. Kebanyakan korban berasal dari daerah Jawa dan bermigrasi ke Malaysia untuk mencari pekerjaan.

Sementara itu, Menteri Hukum dan Hak Azasi Manusia, Andi Mattalata, menyatakan bahwa perdagangan dan penyelundupan manusia terjadi disebabkan oleh empat faktor. Yaitu, keuntungan dari perdagangan manusia sangat besar, budaya (kesamaan bahasa, tertarik dengan budaya luar, pergaulan, gaya hidup dan sebagainya), peluang pekerjaan yang sedikit dan keadaan geografi Indonesia yang membuatkan pemerintah tidak mampu mengontrol terjadinya perdagangan dan penyelundupan pekerja (VivanewsNasional-ILO).

Penelitian yang telah dilakukan menunjukkan beberapa aspek dan kriteria dalam perdagangan orang yaitu:

1. Perdagangan dan penyelundupan wanita dan anak-anak yang dijadikan pembantu rumah tangga atau pekerja domestik.

2. Perdagangan dan penyelundupan wanita dan anak-anak sebagai pekerja di tempat hiburan, kelab malam, pub atau toko.

3. Perdagangan dan penyelundupan wanita dan anak-anak sebagai pekerja seks.

4. Buruh migran.

5. Perkahwinan kontrak bagi mendapatkan anak.

\section{Dampak Perdagangan Penyelundupan Manusia}

dan

anyak dampak yang timbul dari perdagangan dan penyelundupan. Pada satu pihak terdapat dampak psikologi, dan di pihak lain meraup ke untungan ekonomi. Di samping itu pekerjaan yang didapat pekerja migran masuk ilegal melanggar hak asasi manusia kerana pekerjaan yang dilakukan adalah pekerjaan haram (Ilegal). karena itu mereka mera hasiakan pekerjaan mereka. Ini menyebabkan majikan terpaksa mengurung para pekerja ilegal dan perlu berhati-hati sepanjang masa. Gabungan antara dua faktor, penarik (push) dan pendorong (pull) yang mewujudkan pekerja murah dan tidak memiliki keahlian. Keadaan ini tidak hanya berlaku di Indonesia tetapi juga di negaranegara yang sedang membangun dan negara maju.

Dampak kedua ialah keuntungan sosial ekonomi di mana keuntungan dalam bentuk material ini dapat diterima oleh kedua belah pihak baik korban dan juga majikan, walaupun hakikatnya pekerjaan yang dijalankan tidak legal. Walaupun penyelundupan tersebut llegal, korban dapat berhubungan dengan saudaranya di kam 
pung halaman. Mereka juga dapat mengirim uang.

Beberapa kasus yang terjadi saat ini (berdasarkan berita di media cetak serta beberapa hasil penelitian) menunjukkan bahwa kasus perdagangan dan penyelundupan perlu diperhatikan serius. Data-data yang didapat (Irwanto, 2001; Pikiran Rakyat, 2001; Irma Alamsyah, 2000) menunjukkan bahwa:

a. Sebahagian besar korban perdagangan ialah wanita.

b. Laporan dari Kepolisian Republik Indonesia tahun 2000 tercatat 1683 kasus perdagangan wanita dan anak secara ilegal. c. Kasus yang dibicarakan di mahkamah sebanyak 1,094 berasal dari 8 kota besar yang ada di Indonesia.

d. Pada tahun 1999, kasus yang diketahui umum dan diselesaikan ialah sebanyak 1,390 kasus. Sedangkan kasus yang dilaporkan pada masa itu ialah sebanyak 1,712 kasus.

Data berdasarkan lokasi perdagangan dan penyelundupan pekerja migran Indonesia diperincikan dalam Tabel 1.3.

Tabel 1.3 Nama Daerah Asal Pekerja Migran dan Kasus Perdagangan Yang Dapat Diselesaikan Oleh Polisi Indonesia Tahun 1999-2000

\begin{tabular}{lcc}
\hline Kota & Tahun 1999 & Tahun 2000 \\
\hline Surabaya & 313 & 309 \\
Medan & 286 & 282 \\
Manado & 179 & 175 \\
Bandung & 161 & 157 \\
Ujung Pandang & 155 & 151 \\
Padang & 151 & 147 \\
Bali & 133 & 129 \\
Jakarta & 130 & 126 \\
\hline
\end{tabular}

Sumber: Migration News, Ed. 9, no. 3, Maret 2002.

Komisi Nasional Wanita (Komnas Perempuan, 2000) melaporkan bahwa tujuan perdagangan wanita ialah:

a. Pekerja Domestik: wanita dijanjikan dan diberikan kerja sebagai pem bantu rumah tangga.

b. Peminta sedekah: Di Jakarta, Batam, Ujung Pandang dan bebe rapa bandaraya lain, terdapat anakanak yang dibawa oleh orang dewasa untuk meminta sedekah seperti di traffic light dan tempattempat lain.
Data yang diperoleh dari Kedutaan Besar Republik Indonesia (KBRI), kasus perdagangan dan penyelundupan pekerja migran Indonesia di Malaysia berada pada kedudukan kedua berbanding kasus-kasus lain seperti gaji yang tidak di bayar oleh majikan, diusir majikan atau pekerja lari dari majikan, pekerja migran tidak tahan terhadap beban kerja yang berat, pemer kosaan, penganiayaan dan pekerja yang tidak mempunyai kelengkapan persyaratan administrasi imigrasi dan permit kerja yang tidak sah. 
Tabel 1.4 Kasus Pekerja Migran Di Tempat Perlindungan KBRI Kuala Lumpur dalam tempoh Januari hingga Desember 2008

\begin{tabular}{|c|c|c|c|c|c|c|c|c|c|}
\hline Bulan & & & & KES & & & & & \\
\hline & 1 & 2 & 3 & 4 & 5 & 6 & 7 & 8 & 9 \\
\hline & $\begin{array}{c}\text { Gaji } \\
\text { tidak di } \\
\text { bayar }\end{array}$ & $\begin{array}{c}\text { Diusir/ } \\
\text { lari } \\
\text { dari } \\
\text { majika } \\
n\end{array}$ & $\begin{array}{c}\text { Tidak } \\
\text { tahan } \\
\text { kerja }\end{array}$ & $\begin{array}{c}\text { Pemer } \\
\text { kosaa } \\
n\end{array}$ & $\begin{array}{l}\text { Peng- } \\
\text { Aniay } \\
\text { aan }\end{array}$ & $\begin{array}{c}\text { Tiada } \\
\text { dokume } \\
\text { n sah }\end{array}$ & $\begin{array}{c}\text { Per- } \\
\text { dagang } \\
\text { an }\end{array}$ & $\begin{array}{l}\text { Lain- } \\
\text { Lain }\end{array}$ & Jumlah \\
\hline Januari & 26 & 3 & 13 & 1 & 4 & 5 & 6 & - & 58 \\
\hline Februari & 25 & 2 & 12 & 3 & 7 & 5 & 11 & - & 65 \\
\hline Maret & 17 & 3 & 15 & 2 & 5 & - & 9 & 7 & 58 \\
\hline April & 19 & 6 & 8 & - & 6 & 3 & 20 & 24 & 86 \\
\hline Mai & 17 & 7 & 15 & - & 5 & 6 & 12 & 9 & 71 \\
\hline Juni & 17 & 2 & 10 & 3 & 7 & 4 & 17 & 10 & 70 \\
\hline Juli & 15 & 1 & 9 & - & 6 & 11 & 18 & 15 & 75 \\
\hline Agustus & 19 & 3 & 8 & 1 & 3 & 10 & 17 & 6 & 67 \\
\hline $\begin{array}{c}\text { Septembe } \\
r\end{array}$ & 16 & 3 & 7 & 3 & 14 & 5 & 22 & 7 & 77 \\
\hline Oktober & 21 & 3 & 6 & 3 & 9 & 10 & 16 & 5 & 73 \\
\hline November & 8 & 5 & 10 & 4 & 15 & 13 & 16 & 7 & 78 \\
\hline Desember & 7 & 5 & 10 & 3 & 10 & 8 & 6 & 7 & 56 \\
\hline Jumlah & 207 & 43 & 123 & 23 & 91 & 80 & 170 & 97 & 834 \\
\hline
\end{tabular}

Sumber: Data Penampungan Sementara Kedutaan Besar Republik Indonesia 2008

\section{Langkah-langkah untuk mengurangi Kasus Perdagangan dan Penyelundupan Pekerja Migran Indonesia}

$\mathrm{P}$ ersatuan Bangsa-bangsa mendeklara sikan bahwa usaha untuk memerangi kejahatan transnasional dalam semua aspek, termasuk perdagangan dan penyelun dupan manusia dan pencucian uang perlu satu langkah yang intensif" (para 9). (United Nation. 2006).

Sementara itu, dalam Durban Deklarasi dan program Aksi konferensi Dunia 2001 melawan Racism, Racial Discrimination, Xenopobia dan tidak ada toleransi. Mendeklarasikan " kami menegaskan dan mendesak untuk mence gah, memberantas dan menghapuskan segala bentuk perdagangan orang, khususnya wanita dan anak-anak dan mengakui bahwa korban perdagangan khususnya (para 30). Dengan program aksi diantaranya:

a. Migran: mendesak NGO untuk mempertimbangkan imigrasi me ngambil langkah dan menerapkan polisi dan program yang akan memungkinkan imigran, khususnya wanita dan anak-anak yang naif atau korban kekerasan dalam rumah tangga, untuk membebaskan diri dari tindakan kasar. b. Mendesak NGO untuk memperkuat, membentuk, mempromosikan dan melaksanakan perundangan yang efektif, serta langkah-langkah pence gahan yang lain. Di mana situasi yang dialami oleh beberapa kelom pok pekerja adalah serius. Ini termasuk pekerja migran yang merupakan korban perkauman, diskriminasi kaum, dan xenophobia. Perhatian khusus mesti diberikan untuk melindungi mereka yang termasuk pekerja domestik dan korban perdagangan orang dari sebarang bentuk diskriminasi dan kekerasan serta memerangi pra sangka terhadap mereka.

c. Mendesak NGO untuk membuat dan melaksanakan undang-undang membanteras perdagangan orang, terutama wanita dan anak-anak. Ini dilakukan dengan mempertimbang kan bentuk perlakuan yang membahayakan nyawa manusia atau mengakibatkan pelbagai eksploitasi dan perbudakan seperti hutang perbudakan, eksploitasi seksual atau eksploitasi buruh dan mengambil keuntungan dari apa yang dilakukan orang lain untuk kepentingan diri sendiri. Juga mendorong negara untuk membuat mekanisme untuk memerangi kasus perdagangan seperti itu dan 
meletakkan seseorang yang sesuai dengan kemampuan dan keahlian nya. penegakan undang-undang dan perlindungan hak-hak korban, dan untuk memperkuat kerjasama regional, bilateral, dan internasional, termasuk organisasi non pemerintah yang membantu korban, untuk memerangi perdagangan orang dalam penyelundupan pekerja migran.

d. Sanksi dan hukuman kepada tersangka yang bertindak racist Mendesak pemerintah menangani segala bentuk kejahatan perda gangan orang, khususnya wanita dan anak-anak

e. Strategi untuk mencapai keadilan yang sama rata dan efektif, termasuk meningkatkan kerjasama internasional dengan Persatuan bangsa-bangsa.

Untuk mencegah terjadinya kasus perdagangan dan penyelundupan di Indonesia, pemerintah telah mengikat pelaku dan pihak yang terlibat yang melanggar peraturan dan undang-undang. Apabila terbukti melakukan kesalahan dengan saksi dan bukti yang cukup, maka mereka akan dikenakan hukuman. Langkahlangkah tersebut terkandung dalam Kitab Undang-undang Hukum Pidana (KUHP) Indonesia iaitu:

a. Frasa 326 Kitab Undang-undang Hukum Pidana (KUHP); mengan cam dengan penjara selama 9 tahun bagi mereka yang bekerja sebagai anak buah kapal yang mengetahui bahwa kapal itu digunakan untuk perdagangan orang (Fasa ini khas kepada anak buah kapal)

b. Frasa $327 \mathrm{KUHP}$; melarang orang baik dengan pembiayaan sendiri atau orang lain, secara langsung atau tidak langsung turut membantu dalam menyewakan, memuatkan atau menanggung pembayaran sebuah kapal yang diketahui digunakan untuk menjalankan perda gangan budak; hukumannya penjara selama 8 tahun

c. Frasa 328 KUHP; melarikan atau menculik orang, hukumannya pen jara selama 12 tahun.

d. Frasa 329 KUHP menetapkan hukuman penjara selama 7 tahun kepada orang yang dengan sengaja melanggar hak orang lain dan membawa mereka ke tempat lain dari yang dijanji untuk bekerja.

e. Frasa $330 \mathrm{KUHP}$ melarang orang melarikan orang yang belum dewasa dari penjaganya yang sah, dengan hukuman penjara selama 7 tahun dan apabila dilakukan dengan tipu daya atau kekerasan atau ancaman kekerasan, atau korban nya berumur dibawah 12 tahun, hukuman ditambah kepada 12 tahun.

f. Frasa 331 KUHP mengancam dengan hukuman penjara selama 4 tahun atau 7 tahun. Jika umur si anak kurang dari 12 tahun, individu yang sengaja menyembunyikan orang dibawah umur dan mengambil anak tersebut daripada orang yang mengasuhnya.

g. Frasa 332 KUHP: mengancam penjara sekurang-kurangnya 7 tahun, orang yang membawa pergi wanita dibawah umur tanpa persetujuan orang tuanya / walinya, tetapi dengan kehendak wanita berkenaan dengan maksud me nikah. Akan di denda dengan tambahan 9 tahun apabila perbuatan itu dilakukan terhadap wa nita melalui penipuan, kekerasan maupun ancaman kekerasan.

h. Frasa 333 KUHP menetapkan hukuman penjara selama-lamanya 8 tahun bagi orang yang merampas kebebasan orang lain, dan yang menyediakan tempat persembunyian korban.

i. Frasa 460 KUHP: setiap orang yang dengan biaya sendiri atau biaya orang lain secara langsung ataupun tidak langsung menjalankan perdagangan orang, melakukan tindakan perdagangan orang atau turut serta dalam perdagangan orang, dihukum penjara paling lama 12 tahun.

j. Frasa 466 KUHP: setiap orang yang membawa seseorang ke tempat lain, padahal telah membuat perjanjian untuk bekerja di suatu tempat tertentu yang lain, dihukum penjara paling lama 7 tahun. 
k. Direktur Penyidikan dan Penindakan Direktorat Jenderal Keimigrasian R. Muchdor menyatakan modus ope randi perdagangan orang ke luar negeri terutama dalam pemalsuan dokumen semakin canggih. Untuk mengimbangi keadaaan ini, pihak nya menggunakan alat modern seperti adalah biometrik. Dengan alat itu, ia mampu mengetahui cap jari orang dengan cepat.

Dalam deklarasi Copenhagen mengenai pembangunan sosial, memberi komitmen dengan mengambil langkah- langkah efektif, termasuk melalui undangundang dan penerapan undang-undang, serta menjalankan kebijakan untuk me merangi dan menghapuskan segala bentuk diskriminasi, ekspoitasi, pencabulan, dan kekerasan terhadap wanita dan anak-anak, sesuai dengan langkah internasional yang relevan. (Pernyataan 5)."memperkuat usaha ditingkat nasional, termasuk dengan bantuan dari masyarakat internasional, untuk mempromosikan pemberdayaan wa nita, diantaranya dengan menghapuskan segala bentuk kekerasan terhadap wanita, di dalam negara serta di khalayak umum."

\section{Daftar Pustaka}

Arivia, Gadis. 2002. Jurnal Perempuan: Wacana Tubuh Perempuan. Yayasan Jurnal Perempuan. The Ford Foundation dan CIDA.

Azizuddin, M.M.S. 2002. Hak Azasi Manusia; Menurut Pandangan Islam dan Barat. Kuala Lumpur. Cergas Sdn. Bhd.

Berita Harian, 22 Jun 2004

Davies, M. 1994. Woman and Violence. London. St. Martin's Press Inc.

Fakih, Mansur. 2004. Analisis Gender \& Transformasi Social. Yogyakarta. Pustaka Pelajar.

HarianMetro.2004.BendungPerdaganganBebas.http://www.hmetro.com.my/currentnews/Hm/ Tuedag/Mno20040504111614/Article/Indeks_html (12 September 2004).

Heizi. 2005. Pencegahan dan Pentadbiran Dagangan Wanita dan Gadis di Malaysia: Satu Kajian Sosio-Perundangan Terhadap Mangsa Warga Indonesia. Tesis Sarjana. Fakulti Undang-undang. Universiti Kebangsaan Malaysia.

International Labour Office (ILO). Human Trafficking for Sexual exploitation in Japan. Geneva. ILO.

Irianto, Sulistyowati dkk. 2005. Perdagangan Wanita dalam Jaringan Pengedar Narkotika. Jakarta. Yayasan Obor Indonesia.

Irwanto, 2001; Pikiran Rakyat, 2001; Irma Alamsyah, 2000

Ismael, R. \& Malibar, Z. 1996. Wanita dan Pekerjaan. Bangi. University Kebangsaan Malaysia.

Kartono, Nicholasch. 2004. Perdagangan perempuan ke Malaysia tetap marak. http://www.siptakinet.binapenta.go.id. htm 16 jun 2004. 6 Mac 2009.

Laporan Khusus Bangsa-bangsa Bersatu, migrasi Perempuan dan Kekerasan terhadap Perempuan: Penyebab dan Akibatnya, Laporan Pelapor Khusus PBB, Kunci Komnas Perempuan. Jakarta. 2000. hlm 85

Lian, C. P. 2007. "Pengaruh aspek kebajikan ke atas prestasi kerja pembantu rumah warga indonesia dalam daerah Pontian, Johor". Tesis Sarjana. Bimbingan Kaunseling. Universiti Kebangsaan Malaysia.

Migration News. 2002. Ed. 9. 3 Mac.

Mindarti, L. I., 2001. Pemberdayaan Masyarakat Pengrajin Kompor Minyak. Malang. Universitas Brawijaya.

Mohd. Majid Konting, 1990

Mohd. Sheffie Abu Bakar. 1991.

Mosse, J.C., 2004. Gender dan Pembangunan. Yogyakarta. Pustaka Pelajar.

Natalis Pigay. Migrasi dan Penyeludupan manusia tahun 2001-2004. 6 Mac 2009.

Katjasungkana, N., 1997. Pemahaman kritik terhadap peraturan-peraturan hukum tentang perdagangan perempuan. Jakarta. Balai Pustaka.

Ollenburger, J.C. \& Moore, H.A. 2002. Sosiologi Wanita. Jakarta. Rineka Cipta. 
Parawansa, K.I. 2006. Mengukir Paradigma Menembus Tradisi; Pemikiran tentang Kesekaumian Gender. Jakarta. Pustaka LP3ES.

Vermonte, P.J., 1999. Transional Organized Crime Isu dan Permasalahnnya. Ed. Ke-1. Jakarta. Transional Publisher. 44.

Pusat Penelitian Peranan wanita Lembaga Penelitian, Laporan Pengkajian Trafficking Perempuan dan Anak di Jawa Barat, Universitas Padjajaran, Bandung. 2002. hlm 15

Rahim, R.A. 1991. Undang-undang Wanita dan Kanak-kanak. Bandar Baru Bangi. Citra Publishing Sdn. Bhd.

Rahmat Syafaat, Dagangan Manusia, Lappera Pustaka Utama, Yogyakarta, 2003. hlm 11

Ratnawati Yuni Suryandari. 2004. Harga sebuah kebebasan: Isu perdagangan perempuan. http://ccm.um.edu.my/umweb/fsss/images/persidangan/Kertas\%20Kerja/Ratnawati \%20Yuni\%20Suryandari.doc. 6 Mac 2009.

Ruhaini Abd. Kadir (2006) dalam Chin Pek Lian (2007). “Pengaruh Aspek Kebajikan ke atas Prestasi Kerja Pembantu Rumah Warga Indonesia dalam Daerah Pontian, Johor.

United Nation. 6 Mac 2009

Vivanews-Nasional-ILO

Wieringa, S. E. 1999. Penghancuran Gerakan Wanita di Indonesia. Jakarta. Garba Budaya dan Kalyanamitra.

Zakaria, N. 2005. Konsep Hak Asasi Manusia. Kuala Lumpur. Dewan Pustaka dan Bahasa.

Elektronik

Anon. 2002. ironisnya eksploitasi anak untuk dijadikan pengemis ini ternyata dilakukan oleh orangtua, kerabat dekat dan melibatkan tokoh masyarakat setempat). Pikiran Rakyat, 19 Julai: 2002.

Anon. 2006. Pekerja Rumah Tangga diperlakukan Kejam di Seluruh Dunia. Kompas, 25 Julai: 2006

Anon. 2007. Buruh Migran Indonesia di Malaysia. Kompas, 02 Oktober: 2007.

Anon. 2008. Siklus Kekekauman pada Pekerja Migran Terus Terjadi. Kompas, 17 Disember: 2008.

Human Righ Library. 2003. Woman Trafficking. University of Minnesota.

Irma, Alamsyah. D.P. 2000. Aspek Normatif Hukum Terhadap Penghapusan Perdagangan Perempuan dan Anak. Deputi Bidang Pengembangan dan Informasi Kementerian Pemberdayaan Perempuan. Jakarta.

Irwanto et all, op cit, hlm 109-113

Kedubes Amerika Syarikat Jakarta-Indonesia. 2004. Laporan Mengenai PErdagangan Manusia I \& II. Departemen Luar NEgeri Amerika Syarikat, 14 Juni: 2004.

Rehman, J. 2003. International Human Right Law. A Practikal Approach. Longman.

Solidaritas Perempuan (Lembaga Advokasi Buruh Migran Indonesia). 1999. HAM dalam Praktek: Panduan Melawan Perdagangan Perempuan dan Anak. Hal. 5. Bangkok: GAATW.

Soonthornpasuch, Pongrad. 2007. Sexual Hakaumsment: Perception, Measures and Laws in Thailand. University of New South Wales.

UNIFEM. 2007. Kopenhagen.

UNIFEM. 2007. Trafficking in Women. 1995.

UNIFEM. 2007. Fourth World Conference on Women. Beijing. 1995.

UNIFEM. 2007. Second United Nations Confrence on Human settlements (Habitat II). Istanbul. 1996.

UNIFEM. 2007. World Confrence Against Racism, Racial Discrimination, Xenopobia and Related Intolerance. Durban. 2001.

United Nation. 2006. Para 9

United Nation. 2006. The Millennium Development Goals Report.

United Nation. 2008. Office of the High Commissioner for Human Rights, Convention on the Rights of Persons with the Disbilities, 3 May: 2008.

Vivanews-Nasional-Ilo. 2008. Perdagangan manusia di tahun 2009 meningkat. Kompas, 12 Disember. 